\title{
Tourist Satisfaction, Gratitude and Word of Mouth Intention:
}

\author{
An Evidence from Indonesia
}

\author{
Pieter D. Samadara*, Septia S. Dioh, David S. Latupeirissa \\ Business Administration Department \\ State Polytechnic of Kupang \\ Kupang, Indonesia \\ *piter.samdara@pnk.ac.id, septiasakalinidioh@gmail.com, latupeirissadavid1@ gmail.com
}

\begin{abstract}
The goal of the present study is to propose a mediating role of gratitude in the link between tourist satisfaction and positive WoM intention. The data were collected through a survey involving 142 tourists in Indonesia who have experienced tourism services in the country. Based on the data, we managed to find that tourist satisfaction indirectly, at least in part, affect intention to spread positive WoM among tourists through gratitude. Theoretical and practical contributions of the present study were discussed.
\end{abstract}

Keywords-tourist satisfaction, gratitude, positive WoM

\section{INTRODUCTION}

Tourism is one of the drivers of the economy that has been experiencing a very rapid development. As an industry, tourism that relies on services can provide significant economic growth for a country [1]. This is supported by the enormous interest of global tourists who view that tourism as one of the nonphysical needs. The Indonesian government also moved quickly to accommodate the development of the tourism sector in the country by developing infrastructures, especially those related to the tourism sector. One regional area that has been prioritized by the government in developing the tourism sector is East Nusa Tenggara (NTT) province. The development of the NTT economic corridor together with Bali and West Nusa Tenggara (NTB) themed as the Tourism Gateway and National Food Support. This theme is expected to assist in improving welfare in the areas where $17 \%$ of the population live below the poverty line, as well as the existence of income inequality of Rp. 47.2 million per capita between the richest and the poorest districts.

East Nusa Tenggara (NTT) is a province that relies on tourism as one of the main economic activities. NTT Province requires acceleration and expansion of economic development which are focused on 3 (three) main economic activities, namely tourism, fisheries and animal husbandry translated into the agriculture, trade, restaurant and hotel sectors. As one of the important factors that is directly related to the success of the tourism sector in an area, the satisfaction of visiting tourists needs special attention [2]. Previous research noted that tourist satisfaction related to the experience of traveling in the NTT region still needs to be improved [3], for example the development of infrastructure and service facilities [4]. Therefore, the authors are interested in conducting research on marketing strategies carried out by tourism managers in NTT, specifically how the relationship between satisfaction with the willingness of tourists to recommend their positive tourism experience to others is mediated by gratitude.

This study aims to discover the mediating role of gratitude in the relationship between tourist satisfaction and intention to spread positive Word of Mouth (WoM) to others. Previous research has found that tourist satisfaction has a direct effect on the interest in spreading WoM to others $[5,6]$. This study extends the prior study by proposing gratitude as the mediating factor in the relationship.

\section{LITERATURE REVIEW}

\section{A. Tourist Satisfaction and Gratitude}

Tourist satisfaction in tourism services is a crucial component that can determine the desire of tourists to revisit [7] as well as the willingness of tourists to recommend tourism services to others [8]. Given the important role of tourist satisfaction, this aspect received special attention from both practitioners and academics. Satisfaction is closely related to consumer expectations and is defined as general feelings or emotions that come from confirmed expectations [9]. This implies that satisfaction has a strong effect on what consumers feel about what is offered by the goods or services they experience. In this case, satisfaction is seen as a subjective feeling that indicates the extent to which expectations for a transaction of goods or services can be fulfilled or not [8]. Žabkar, et al. [10] argue that tourist satisfaction is an accumulation of several tourist experiences including interactions with individuals and organizations involved in tourism services. 
Gratitude is described as an emotion consisting of three components, namely appreciation of someone or something, good intentions to someone and a tendency to do things based on appreciation and good intentions [11]. There are 2 (two) aspects of gratitude, affective and behaviour. Affective aspects are feelings of gratitude that are created when a person places himself as a recipient of a benefit, while the behavioural aspect refers to the psychological force to reciprocate to those who have done good to an individual [12]

In the field of consumer behavioural, researchers find that consumers tend to realize and appreciate the hard efforts of producers to market their products and provide benefits to consumers, and subsequently feel grateful [13]. In the context of tourism, it can be predicted that when people are satisfied with the tourism services, they would feel more gratitude. The relationship between gratitude and satisfaction can be found in previous studies [14-16]. These scholars argue that people who feel grateful for something also experience positive emotions like happiness and feel being accepted and valued.

\section{B. Tourist Satisfaction and Positive WoM Intention}

Tourism has become a big industry and has been showing a rapid and consistent growth. The World Tourism Organization estimates that tourism will be one of the biggest contributors to countries' economy given the increasing number of tourist arrivals. Modern tourism is supported by globalization which is closely related to the spread of information among individuals regardless of space barriers [17]. The quick process of disseminating information is supported by technological developments, especially the internet through websites and social media. Indeed, with the internet, everyone has access to the internet and can automatically become a source of information for services, including tourism services.

Tourist satisfaction regarding tourist services has been shown to correlate with a variety of positive impressions from tourists. For example, Abubakar and Mavondo [8] found that tourists are willing to spread positive WoM if they emotionally experience happiness and pleasure with the services offered. In addition, the tendency to spread positive WoM decreases if they experience interference and anxiety during the tour. Research by Abubakar and Mavondo [8] also found that happiness, pleasure, disturbance and anxiety affect tourist satisfaction. Furthermore, previous studies have suggested that tourist satisfaction has a positive effect on the willingness of the tourists concerned to spread positive WoM [5,18]. The information about the perceived satisfaction is shared with other tourists because they want to get a positive impression about themselves.

Prior studies have found that consumers' feeling of gratitude may increase the willingness to spread positive WOM [2,19]. Soscia [19] argue that grateful individuals tend to reciprocate by promoting the well-being of the service provider, and one way to do so is by spreading positive WOM to friends and relatives. Similar finding was revealed in free online context where consumers have positive WOM intention when they are grateful to the values offered by companies [2].
Based on the prior literature, we predict that tourist satisfaction affects gratitude which in turn influences positive WoM intention among tourists.

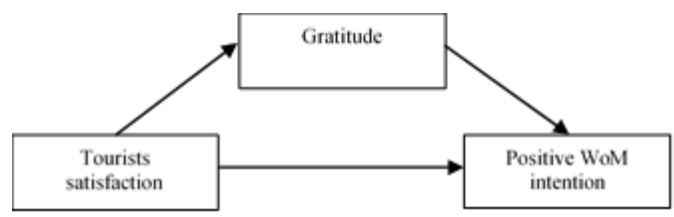

Fig. 1. The mediating role of gratitude in the link between tourist satisfaction and positive WoM intention.

\section{METHODS}

\section{A. Samples and Data Collection}

Respondents in this study were 142 tourists, both foreign and local tourists in the Kupang City, the capital of the province of East Nusa Tenggara. The respondents were selected based on a convenience sampling procedure. The respondent are adults, willing without coercion to fill out questionnaires, have experience in visiting the city of Kupang, and do not aware of the hypothesis of this study. The respondents did not receive any reward for participating. They could stop participating at any point if they feel uncomfortable.

Three cafés in Kupang were selected as sites of data collection. The respondents were approached and were politely asked to involve in the survey. They were informed that the purpose of this scientific research was to investigate the perspective of tourists regarding the facilities and services of tourist attractions in Kupang.

\section{B. Measures}

The scales in the survey were adapted from previous studies which had passed validity and reliability tests. Gratitude measurement is a 3-item scale adapted from Palmatier, et al. [20]. The sample question is, "I feel grateful with the service provided by this café." The scale of tourist satisfaction is adapted from a study conducted by Kozak and Rimmington [18]. The sample question of the 4-item scale is, "Quality and variety of food served by this café are excellent." While the intention to spread positive WoM was adapted from a prior study by Abubakar and Mavondo [8]. The sample question is, "I am happy to share this experience with my family and friends." All variables were measured with a 7-point Likert scale.

\section{Analysis Technique}

To examine the research model, we used SmartPLS 3 to assess both the measurement and the structural model or hypothesis testing [21]. Unlike traditional Structural Equation Model (SEM), Partial Least Square (PLS) modelling is employed as an alternative method to examine covariancebased SEM which does not require the goodness of fit index reporting [22]. 


\section{RESULTS}

\section{A. Measurement Model}

The construct validity and reliability were inspected before testing the hypotheses. The convergent validity and the Average Variance Extracted (AVE) were examined by inspecting the item loadings and the p-values. The variables were examined for their reliability. All indicators' outer loadings are greater than the threshold [23]. The AVE values for the scales were above the expected value of 0.50 , indicating that convergent validity is satisfied (Table 2). The results showed that the variables were in sufficient levels of reliability as exhibited in Table 1 according to Hinton, et al. [24].

TABLE I. COMPOSITE RELIABILITY AND CRONBACH ALPHA

\begin{tabular}{|c|l|l|l|}
\hline \multicolumn{2}{|c|}{ Constructs } & \multicolumn{1}{|c|}{$\begin{array}{c}\text { Composite } \\
\text { Reliability }\end{array}$} & $\begin{array}{c}\text { Cronbach } \\
\text { Alpha }\end{array}$ \\
\hline 1. & Gratitude & .79 & .67 \\
\hline 2. & Tourists satisfaction & .83 & .74 \\
\hline 3. & Positive WoM intent & .89 & .84 \\
\hline
\end{tabular}

The multicollinearity problems were observed through examining the Variance Inflation Factor (VIF) values. The results showed that VIF of all indicators were below the value of 5 as the suggested threshold [25].

TABLE II. AVE, DESCRIPTIVE STATISTICS AND CORRELATIONS

\begin{tabular}{|l|l|l|l|l|c|c|}
\hline \multicolumn{2}{|c|}{ Variable } & AVE & Mean & SD & 1 & $\mathbf{2}$ \\
\hline 1. & Gratitude & .65 & 6.56 & .93 & & \\
\hline 2. & Tourists satisfaction & .56 & 5.60 & 1.39 & $.25^{* *}$ & \\
\hline 3. & Positive WoM intent & .67 & 5.82 & 1.54 & $.33^{* *}$ & $.45^{* *}$ \\
\hline
\end{tabular}

\section{B. Hypothesis Testing}

To examine the model, tourist satisfaction gratitude positive WoM intention, the data were tested with a mediation analysis using bootstrap technique with 5,000 resamples.

The results showed that satisfaction positively affected gratitude $(\beta=.31, \mathrm{t}=3.01)$, indicating that when the tourists are satisfied with the services, they are more grateful with the services. Gratitude was also associated with intention to spread WoM among the tourists $(\beta=.27, \mathrm{t}=2.25)$. The tourist satisfaction has a direct effect on positive WoM intention $(\beta=$ $.41, \mathrm{t}=3.96)$, meaning that the more people satisfied, the more they have intention to spread positive WoM regarding the tourism services. More importantly, the indirect effect of satisfaction on positive WoM intention through gratitude was significant $(\beta=.06, \mathrm{CI}=.03 ; .16)$.

\section{DISCUSSION}

This study uncovers the mediating role of gratitude in the relationship between tourist satisfaction and positive WoM intention. The finding is essential since it extends prior findings regarding the link between satisfaction and positive WoM intention $[5,26]$ by establishing the mediating role of gratitude. Therefore, this study presents a theoretical clarification of the link between tourist satisfaction and positive WoM intention, particularly in a tourism context.

Word of mouth is an important factor in marketing, including in tourism marketing. The emergence of gratitude as an antecedent of positive WoM intention may assist practitioners to design appealing tourism campaign. For example, demonstrating intense efforts in fulfilling tourists needs and wants may evoke the feeling of gratitude among tourists [13], thus, in turn will increase the intention to spread positive WoM as well as revisit intention.

Several limitations in this study are acknowledged. First, this study was conducted only in Kupang, an eastern part Indonesia. While the country has multicultural ethnics, the people of Kupang may hold different characteristics than other parts of Indonesia. This may cause variation in how people express their feelings of gratitude. Future studies may resolve this issue by conducting data collection from different places in Indonesia which represent the multicultural aspect of the country. Second, this study did not account for the personality trait of the respondents. Future studies may include personality traits as controlling variables in the analysis. This is beneficial as to see which type of traits that influences level of gratitude in responding to tourist services.

\section{CONCLUSION}

The objective of this research is to confirm the mediating role of gratitude in the relationship between tourists satisfaction and positive WoM intent. We have analyzed the data collected from tourists in Kupang, Indonesia. The results indicated that our hypotheses were confirmed. The implications of the current study are presented in terms of both practical and theoretical contributions.

\section{REFERENCES}

[1] S. Koubida, M. Small, and M. Yasin, "An Analysis of the Competitiveness of the Moroccan Tourism Industry: Implications for Policy Development and Implementation," Journal of Competitiveness Studies, vol. 25, no. 3/4, pp. 231-249, 2017.

[2] P. D. Samadara and J. P. Fanggidae, "The Role of Perceived Value and Gratitude on Positive Electronic Word of Mouth Intention in the Context of Free Online Content," International Journal of Innovation, Creativity and Change, vol. 11, no. 10, pp. 391-405, 2020.

[3] J. P. Fanggidae and K. K. Adoe, "Model Atribut Obyek Wisata dan Kepuasan Wisatawan di Pantai Nemberala Kabupaten Rote Ndao Provinsi Nusa Tenggara Timur," Jurnal Penelitian Manajemen Terapan (PENATARAN), vol. 2, no. 1, pp. 57-68, 2017.

[4] M. M. Attubel, "Pengambilan Keputusan Wisatawan Berkunjung di Nusatenggara Timur Melalui Bauran Pemasaran Jasa Pariwisata," Jurnal Ilmiah Pariwisata, vol. 18, no. 3, pp. 216-230, 2013.

[5] N. Prebensen, K. Skallerud, and J. S. Chen, "Tourist motivation with sun and sand destinations: satisfaction and the wom-effect," Journal of Travel \& Tourism Marketing, vol. 27, no. 8, pp. 858-873, 2010.

[6] Y. Wardi, A. Abror, and O. Trinanda, "Halal tourism: antecedent of tourist's satisfaction and word of mouth (WOM)," Asia Pacific Journal of Tourism Research, vol. 23, no. 5, pp. 463-472, 2018. 
[7] J. Alegre and J. Garau, "Tourist satisfaction and dissatisfaction," Annals of tourism research, vol. 37, no. 1, pp. 52-73, 2010.

[8] B. Abubakar and F. Mavondo, "Tourism destinations: Antecedents to customer satisfaction and positive word-of-mouth," Journal of Hospitality Marketing Management, vol. 23, no. 8, pp. 833-864, 2014.

[9] R. N. Bolton and J. H. Drew, "A multistage model of customers' assessments of service quality and value," Journal of consumer research, vol. 17, no. 4, pp. 375-384, 1991.

[10] V. Žabkar, M. M. Brenčič, and T. Dmitrović, "Modelling perceived quality, visitor satisfaction and behavioural intentions at the destination level," Tourism management, vol. 31, no. 4, pp. 537-546, 2010.

[11] P. Fitzgerald, "Gratitude and Justice," Ethics, vol. 109, no. 1, pp. 119$153,1998$.

[12] R. A. Emmons and M. E. McCullough, The psychology of gratitude (no. Book, Whole). Oxford;New York;: Oxford University Press, 2004.

[13] Andrea C. Morales, "Giving Firms an "E" for Effort: Consumer Responses to High-Effort Firms," Journal of Consumer Research, vol. 31, no. 4, pp. 806-812, 2005.

[14] M. E. McCullough, R. A. Emmons, and J.-A. Tsang, "The grateful disposition: A conceptual and empirical topography," Journal of Personality Social Psychology, vol. 82, no. 1, p. 112, 2002.

[15] L. Waters, "Predicting job satisfaction: Contributions of individual gratitude and institutionalized gratitude," Psychology, vol. 3, no. 12A special issue, p. 1174, 2012.

[16] A. M. Wood, S. Joseph, and J. Maltby, "Gratitude predicts psychological well-being above the Big Five facets," Personality and Individual Differences, vol. 46, no. 4, pp. 443-447, 2009.

[17] I. G. B. R. Utama and M. SE, Pengantar Industri Pariwisata. Deepublish, 2015.
[18] M. Kozak and M. Rimmington, "Tourist satisfaction with Mallorca, Spain, as an off-season holiday destination," Journal of Travel Research, vol. 38 , no. 3, pp. 260-269, 2000.

[19] I. Soscia, "Gratitude, delight, or guilt: The role of consumers' emotions in predicting postconsumption behaviors," Psychology and Marketing, vol. 24, no. 10, pp. 871-894, 2007.

[20] R. W. Palmatier, C. B. Jarvis, J. R. Bechkoff, and F. R. Kardes, "The Role of Customer Gratitude in Relationship Marketing," Journal of Marketing, vol. 73, no. 5, pp. 1-18, 2009.

[21] C. M. Ringle, S. Wende, and J.-M. Becker, "SmartPLS 3. Hamburg: SmartPLS," Academy of Management Review, vol. 9, pp. 419-445, 2014.

[22] E. E. Rigdon, "Structural equation modeling: nontraditional alternatives," Wiley StatsRef: Statistics Reference Online, pp. 1-12, 2014.

[23] W. W. Chin, "The partial least squares approach to structural equation modeling," Modern methods for business research, vol. 295, no. 2, pp. 295-336, 1998.

[24] P. R. Hinton, I. McMurray, and C. Brownlow, SPSS explained. Routledge, 2014.

[25] A. Diamantopoulos and H. M. Winklhofer, "Index construction with formative indicators: An alternative to scale development," Journal of marketing research, vol. 38, no. 2, pp. 269-277, 2001.

[26] J.-A. Tsang, T. P. Carpenter, J. A. Roberts, M. B. Frisch, and R. D. Carlisle, "Why are materialists less happy? The role of gratitude and need satisfaction in the relationship between materialism and life satisfaction," Personality and individual differences, vol. 64, pp. 62-66, 2014. 